\title{
Intraenterprise Antitrust Conspiracy: A Decisionmaking Approach
}

Section 1 of the Sherman Act prohibits "[e]very contract, combimation . . . or conspiracy, in restraint of trade." 1 The purpose of this section was to prohibit cartel behavior, ${ }^{2}$ restore competition, and eliminate price distortions resulting from collusion. ${ }^{3}$ Section 1 achieves these results by preserving "independent centers of initiative." 4 Since only collusion between separate entities can diminish these sources of initiative, Congress made a "plurality of actors" requisite to finding a section 1 violation. ${ }^{5}$ Trade restraints resulting from acts within a single corporate entity, therefore, do not give rise to liability under that section. ${ }^{6}$

The antitrust doctrime of intraenterprise conspiracy ${ }^{7}$ rests on the

1. Sherman Antitrust Act, 15 U.S.C. \& 1 (1982).

2. Standard Oil Co. v. United States, 221 U.S. 1, 50 (1911). For a conuplete history of the Sherman Act, see Letwin, Congress and the Sherman Antitrust Law: 1887-1890, 23 U. CHI. L. REv. 221 (1956).

3. See United States v. Trenton Potteries Co., 273 U.S. 392, 397 (1927); see also C. KAYSEN \& D. TURner, ANTITRUST Policy 19 (1959).

4. McQnade, Conspiracy, Multicorporate Enterprises, and Section 1 of the Sherman Act, 41 VA. L. REv. 183, 185 (1955); see also Handler \& Smart, The Present Status of the Intra-Corporate Conspiracy Doctrine, 3 CARDozo L. REv. 23, 73 (1981); Note, Intra-Enterprise Conspiracy Under Section 1 of the Sherman Act: A Suggested Standard, 75 MrCH. L. Rev. 717, 737 (1977).

5. See, e.g., Independence Tube Corp. v. Copperweld Corp., 691 F.2d 310, 316 (7th Cir. 1982), cert. granted, 103 S. Ct. 3109 (1983) (No. 82-1260); Knutson v. Daily Review, Inc., 548 F.2d 795 (9th Cir. 1976) ( $\$ 1$ can be violated only by two separate entities acting in concert), cert. denied, 433 U.S. 910 (1977); Nelson Radio \& Supply Co. v. Motorola, lnc., 200 F.2d 911, 914 (5th Cir. 1952), cert. denied, 345 U.S. 925 (1953); see also Report of THE ATtorney General's National Committee to Study the Antitrust Laws 30 (1955) [hereinafter cited as ATtorNEY GeNeral's ReporT]; L. SUlLIVAN, HaNDBOOK OF THE LAW OF ANTITRUST § 108 (1977). To recover under \& 1, a plaintiff nust show (1) the existence of a contract, combination, or conspiracy; (2) an unreasonable restraint of trade; and (3) an antitrust imjury. Handler \& Smart, supra note 4 , at 67 .

6. For instance, although two firms cannot jointly refuse to deal with a third party, a single firm acting alone may so refuse. See United States v. Colgate \& Co., 250 U.S. 300, 307 (1919). Single firm restraimts of trade are, however, subject to $\S 2$ of the Sherman Act. Section 2 prohibits monopolization and attenpts to monopolize, whether by unilateral conduct or joimt activity. It also prohibits conspiracy to nonopolize. 15 U.S.C. $\$ 2$ (1982). To recover under $\$ 2$, the plaintiff must prove (1) specific intent to monopolize; (2) conduct designed to implement that intent; (3) a dangerous probability of success, or (a) possession of monopoly power and (b) antitrust mjury. Handler \& Smart, supra note 4, at 67 . As currently construed, \& 2 can reach only a narrow range of cases where single firm anticompetitive conduct is present. NATIONAL COMMISSION FOR THE Review of the Antitrust laws and Procedures, Report to the President and the AtTORNEY GENERAL 145 (1979). For instance, a recent trend in court decisions is to regard prices at levels above marginal or average variable costs as conclusive evidence of a lack of intent or effect necessary to establish attempted monopolization. Id; see Hanson v. Shell Oil Co., 541 F.2d 1352, 1358 (9th Cir. 1976), cert. denied, 429 U.S. 1074 (1977).

7. This Comment advocates a standard that does not distinguish between separately incor- 
premise that certain multidivisional business enterprises contain within them the plurality of actors necessary to meet section 1's "combination" or "conspiracy" requirement. When agreements between these actors restrain trade, the doctrine asserts, the enterprise should be subject to the same antitrust sanctions that apply to joint actions of enterprises that do not share the coincidence of common ownership.

The Supreme Court has developed a "separate incorporation" test with which to ascertain corporate exposure to intraenterprise conspiracy liability. Taken together, its opinions suggest that when corporate subdivisions have been separately incorporated, they are to be treated as separate entities for the purpose of applying section $1 .^{8}$ Internal decisions made among these subsidiaries or with the parent company are, therefore, subject to section 1 liability as an illegal conspiracy if they restrain the trade of outsiders. ${ }^{9}$ Commentators are nearly unanimous

porated and unincorporated subdivisions of an enterprise. The term "intraenterprise conspiracy," therefore, will refer to any intracorporate agreennent which the plaintiff alleges to be a conspiracy, regardless of the corporate status of the subsidiaries. This construction deviates from that of inany courts and commentators, who have restricted "intraenterprise conspiracy" only to those involving separately incorporated divisions and have designated "intracorporate conspiracy" to describe agreements involving unincorporated subdivisions. See, e.g., Independence Tube Corp. v. Copperweld Corp., 691 F.2d 310, 316 n.2 (7th Cir. 1982), cert. granted, 103 S. Ct. 3109 (1983) (No. 821260); Kempf, Bathtub Conspiracies: Has Seagram Distilled a More Potent Brew?, 24 BUS. LAW. 173, 173 (1968); Willis \& Pitofsky, Antitrust Consequences of Using Corporate Subsidiaries, 43 N.Y.U. L. REv. 20, 25 (1968); Note, "Conspiring Entities" Under Section I of the Sherman Act, 95 HARv. L. REv. 661, 662 (1982) (using "intracorporate conspiracy" to refer also to agreements between a corporation and its officers); Note, supra note 4 , at 717 n.4.

8. See Perma Life Muffiers, Inc. v. International Parts Corp., 392 U.S. 134 (1968); Timken Roller Bearing Co. v. United States, 341 U.S. 593 (1951); Kiefer-Stewart Co. v. Joseph E. Seagrain \& Sons, Inc., 340 U.S. 211 (1951); Schine Chain Theatres, Inc. v. United States, 334 U.S. 110 (1948); United States v. Yellow Cab Co., 332 U.S. 218 (1947); see also Independence Tube Corp. v. Copperweld Corp., 691 F.2d 310, 317 n.8 (7th Cir. 1982), cert. granted, 103 S. Ct. 3109 (1983) (No. 82-1260).

9. In each of the five intraenterprise cases decided by the Supreme Court, the intraenterprise agreement that was the focus of the complaint injured outside third parties. This fact has prompted commentators to read the Court's doctrine as requiring not only that the agreenent have been made by separate entities within a business enterprise, but also that the agreement restrain the trade of outside parties. See ATTORNEY GENERAL's REPORT, supra note 5, at 34 ("where . . . concerted action restrains no trade and is designed to restrain no trade other than that of the parent and its subsidiaries, Section 1 is not violated."); L. Sullrvan, supra note 5 , $\S 114$, at 328. For judicial applications of this distinction, see Thomscn v. Westcrn Elec. Co., 680 F.2d 1263, 1266 (9th Cir.), cert. denied, 103 S. Ct. 348 (1982); Murphy Tugboat Co. v. Shipowners \& Merchants Towboat Co., 467 F. Supp. 841, 860 (N.D. Cal. 1979), affd sub nom. Murphy Tugboat Co. v. Crowley, 658 F.2d 1256 (9th Cir. 1981), cert. denied, 455 U.S. 1018 (1982); Chastain v. American Tel. \& Tel. Co., 401 F. Supp. 151, $159-60$ (D.D.C. 1975). But see Handler \& Sinart, supra note 4, at 50-51 (noting that the requirement of third party trade restraints provides little hinitation on the Supreme Court doctrine, since most intraenterprise agreements are likely to have some effect on outsiders); Brief for the United States as Amicus Curiae Supporting Petitioners at 15, Copperweld Corp. v. Independence Tube Corp., 103 S. Ct. 3109 (1983) (No. 82-1260).

This comment is concerned only with the first elemeut of $\$ 1$ 's statutory requirements-at what poimt should courts consider corporate subdivisions separate entities for the purposes of satisfying the "plurality of actors" required for a conspiracy or combination. An evaluation of the 
in their criticism of the Court's formalistic doctrine. ${ }^{10}$ Separate incorporation, they argue, reveals little about the true independence of a subsidiary from its parent.

The circuit courts, also recognizing the disparity between the Court's legal doctrine and the statutory purposes of section 1 , have joined in the criticism. ${ }^{11}$ The Seventh, Eighth, and Ninth Circuits, departing from the formalistic analysis commended by the Supreme Court, ${ }^{12}$ have developed a more fact-sensitive approach with which to determine whether subdivisions can conspire among theinselves or with their parents. These courts have adopted a new test that examines the functional relationship between corporate units to determine whether they constitute separate corporate entities capable of conspiring to restraim trade. ${ }^{13}$ This "functional" test, lowever, has its own weaknesses.

In the midst of the growing disquiet and confusion, the Supreme Court has granted certiorari on the issue of intraenterprise conspiracy in Independence Tube Co. v. Copperweld Corp. ${ }^{14}$ In Copperweld the Court will juxtapose its formalistic approacl with the "functional relationship" standard as applied by the Seventh Circuit. The Supreme Court has four choices: (1) accede to the Seventl Circuit's standard, (2) reject it as mconsistent witl the Court's own separate incorporation standard, (3) adopt an entirely new standard, or (4) repudiate alto-

second requirement of $\S 1$ to ascertain whether internal agreements, absent any effect on parties outside the corporation, meet the restraint of trade threshold is beyond the scope of this analysis.

10. An abbreviated bibliography of the leading commentary on intraenterprise conspiracy includes: Barndt, Two Trees or One?-The Problem of Intra-Enterprise Conspiracy, 23 MoNT. L. REv. 158 (1962); Blecher \& Daniels, Professional Sports and the "Single Entity" Defense Under Section One of the Sherman Act, 4 WHITTIER L. REv. 217 (1982); Handler, Through the Antitust Looking Glass-Twenty-First Annual Antitust Review, 57 CALIF. L. Rev. 182 (1969); Handler \& Sınart, supra note 4; Keinpf, supra note 7; McQuade, supra note 4; Willis \& Pitofsky, supra notc 7; Comment, All in the Family: When Will Internal Discussions Be Labeled Intra-Enterprise Conspiracy?, 14 DuQ. L. Rev. 63 (1975); Note, supra note 7; Note, supra note 4. For a more extensive list, see Handler \& Smart, supra note 4, at 23 n.3.

11. See, e.g., Independence Tube Corp. v. Copperweld Corp., 691 F.2d 310, 317-18 (7th Cir. 1982) (noting that although the commentary concerning intraenterprise hability has been universally critical, courts are required to be more constrained in their dissent, given the existing Supreme Court decisions), cert. granted, 103 S. Ct. 3109 (1983) (No. 82-1260); Ogilvie v. Fotomat Corp., 641 F.2d 581, 588 (8th Cir. 1981) (formality of permitting separate incorporation to foreclose a single entity defense elevates form over substance); George R. Whitten, J., Inc. v. Paddock Pool Builders, Inc., 508 F.2d 547, 557 (1st Cir. 1974) (acknowledging the criticisms of the separate incorporation standard, but applying it nonetheless), cert. denied, 421 U.S. 1004 (1975).

12. See Ogilvie v. Fotomat Corp., 641 F.2d 581 (8th Cir. 1981); Photovest Corp. v. Fotomat Corp., 606 F.2d 704 (7th Cir. 1979), cert. denied, 445 U.S. 917 (1980); Knutson v. Daily Rcview, Inc., 548 F.2d 795 (9th Cir. 1976), cert. denied, 433 U.S. 910 (1977). For an outstanding summary of the efforts by circuit courts to limit the reach of the Supreme Court's separate incorporation test, see Handler \& Sinart, supra note 4, at 38-61. See also Note, supre note 7, at 666-76.

13. See infra text accompanying notes $78-100$.

14. 691 F.2d 310 (7th Cir. 1982), cert. granted, 103 S. Ct. 3109 (1983) (No. 82-1260). 
gether the doctrine of intraenterprise conspiracy. ${ }^{15}$

This Comment reassesses the intraenterprise conspiracy doctrine. Part I presents the historical context in which the doctrine inust be evaluated. Part II begins by considering how the ideal antitrust law would fashion a rule of intraenterprise conspiracy. It then reviews the formahstic and functional standards developed by the courts and examines their strengths and weaknesses. Part III proposes that courts examine the allocation of decisionmaking authority within a business enterprise to determine whether its subunits are truly separate, autonomous entities capable of antitrust conspiracy. This alternative standard responds to the pohicies underlying section 1 of the Sherman Act and is more consistent with the structural realities of American business than any of the existing variations of the doctrine.

\section{I \\ The Historical Context}

\section{A. The Birth of Decentralized Structures}

Defining a single corporate entity exempt froin the proscriptions of section 1 was easy in 1890, when Congress passed the Sherman Act. Although some companies had grown large through vertical integration or horizontal combination, ${ }^{16}$ they retained centrally organized administrative structures, with responsibility for all operating and strategic decisions residing in top management. ${ }^{17}$ Cartel conduct among these distmct competitors was easily discermible.

The notion of a single entity, however, became blurred with the advent of diversified industrial corporations. In the early decades of the twentieth century, many industrial corporations sought to exploit new market opportunities by expanding their product lines, geographic markets and business activities. ${ }^{18}$ In response to the disparate needs created by the new industrial strategy, these companies adopted new administrative formats, ${ }^{19}$ replacing centralized structures with inultidivisional, decentralized ones. Corporate executives created subdivi-

15. Two recent articles advocate rejection of the intraenterprise conspiracy doctrine where agreements between wholly owned subsidiaries and their parents are at issue. See Handler \& Smart, supra note 4, at 25; Note, supra note 7, at 681. The Attorney General has also endorsed this position in the Department of Justice's amicus brief in Copperweld. Brief for the United States as Amicus Curiae Supporting Petitioners at 22-23, Copperweld Corp. v. Independence Tube Corp., 103 S. Ct. 3109 (1983) (No. 82-1260).

16. See A. Chandler, Strategy ANd Structure 30-31 (1962); see also W. Brownlee, DYNAMICS OF ASCENT 198-204 (1974).

17. A. Chandler, supra note 16 , at 31,41 .

18. Id at $42-43$.

19. Id. at $48-49$. 
sions, some separately incorporated, ${ }^{20}$ to respond to unique product, functional, or geographic demands. They placed quasi-autonomous corporate managers im charge of these subdivisions and gave them responsibility for day-to-day operational decisions. ${ }^{21}$ For instance, a decentralized subdivision manager may have been given authority to hire and fire employees, make supply and sales contracts, explore new market opportunities, and monitor inventories. Relieved of these responsibilities, senior executives were able to concentrate on controlling and coordinatimg the overall activities of the enterprise. The central office developed long-term plans for growth and expansion and directed the allocation of corporate resources necessary to achieve these strategies. Only top management could decide, for example, to sell or acquire business interests or to imtroduce new products or services. ${ }^{22}$

Decentralization produced real economic advantages for diversified corporations. ${ }^{23}$ The large variety of corporate operational decisions could now be made by those with the greatest cxpertise and implemented at the level where it was easicst to respond to constant changes in the marketplace. ${ }^{24}$ The corporation also benefited from the specialization of top management. Relieved of operating duties, the central office could be detached from the parochial interests of each subdivision. It could consider the strategic allocation of resources with the long-term direction of the entire corporation in mind. In addition, top managers could investigate new areas for development or expansion in which the operating executives would have little interest or knowledge. 25

Courts construing the provisions of section 1 have been slow to recognize this organizational evolution. Many continue to regard relationships between parent companies and their decentralized operating

20. Adolf Berle, Jr. described the appearance of separately incorporated subsidiaries as follows:

As the scale of business enterprises enlarged, the process of sub-division began; hence subsidiary corporations wholly-owned or partly-owned ..... More often than not, a single large-scale business is conducted, not by a single corporation, but by a constellation of corporatious controlled by a central holding coinpany, the various sectors being separately incorporated, either because they were once independent and have been acquired, or because the central concern, entering new fields, created new corporations to develop thein, or for tax reasons. In soine instances, departments of the business are separately incorporated and operated as separate legal units.

Berle, The Theory of Enterprise Entity, 47 Colum. L. REv. 343, 343 (1947).

21. A. Chandler, supra note 16 , at 311 .

22. Id. at 310 .

23. Id. at 16.

24. In contrast, centralized structures aggregating such authority were unable to react to market fluctuations with equal sensitivity. Where the peculiarities of a subdivision's market or supply conditions demanded tailor-made decisions, top managennent was insufficiently informcd to detect these demands and too remote to effect responsive strategies. Id. at 393.

25. Id. at 310 . 
units with considerable suspicion. Much doctrinal confusion has arisen over the question of whether and when a multidivisional corporate structure may be said to contain within it the plurality of actors required for a section 1 conspiracy.

\section{B. General Motors: A Case Study}

United States v. General Motors Corp. ${ }^{26}$ was the first case to hold that an agreement between a parent coinpany and its subsidiaries violated section 1. Although this case did not reach the Supreme Court, it is an integral part of the historical context in which the doctrine of intraenterprise conspiracy should be evaluated.

General Motors was a pioneer in the use of decentralized administrative structures. During the first two decades of this century, General Motors expanded rapidly to meet the growing market for automotive products and services. The company's centralized administrative structure, overburdened by the new decisionmaking demands such growth created, was unable to maintain adequate control over its operations. The company faced a financial crisis. In an effort to avert disaster, the company adopted an innovative structure that allowed it to administer separately incorporated operating divisions through a central organization of general officers and staff executives. ${ }^{27}$ Substantially autonomous subdivisions carried out routine business affairs, while the firm's central office coordinated and controlled the company's overall activities. ${ }^{28}$ This structure enabled General Motors to execute its strategy of expansion and to regain its financial footing. ${ }^{29}$

General Motors' decision to alter its administrative format, however, was not without legal ramifications. To the Seventh Circuit Court of Appeals, ${ }^{30}$ the company's new corporate structure reseinbled an

26. 121 F.2d 376 (7th Cir.), cert. denied, 314 U.S. 618 (1941). In General Motors, the Government charged the corporation and three separately incorporatcd financing and sales divisions with a conspiracy to violate $\$ 1$. The complaint alleged that the defendants had colluded to coerce individual dealers into financing their new car inventory and retail sales through General Motors.

27. A. Chander, supra note 16 , at 128-30.

28. 121 F.2d at 385-86; A. ChANDLER, supra note 16, at 140, 158.

29. A. Chander, supra note 16 , at $158-60$.

30. The Seventh Circuit rejected the company's description of itself as a single trader, stating: "Nor can the appellants enjoy the benefits of separate corporate identity and escape the consequences . . . by insisting that they are in effect a single trader." $121 \mathrm{~F} .2 \mathrm{~d}$ at 404 . What the court meant by "separate corporate identity" is unclear, since the record disclosed both that the General Motors subsidiaries were incorporated separately from the parent and that they were operationally autonomous.

For further discussion of the General Motors case, see Handler \& Smart, supra note 4, at 27 (noting that the Seventh Circuit provided no authority or logic for its holding); Willis \& Pitofsky, supra note 7, at 41-42 (arguing that the intraenterprise conspiracy doctrine was not necessary to establish substantive liability in that case). 
amalgam of independent firms capable of conspiring - and in this case having conspired-to restrain trade.

The lesson to be learned from General Motors' history is that businesses do not choose their structures arbitrarily. Rather, executives select structures as tools of corporate strategy. A firm adopts its particular structure out of a belief that it is the most efficient and effective vehicle for achieving the long-term goals of the enterprise. The refusal of the Seventh Circuit in General Motors to perceive the legitimate business considerations implicit in a company's decision to use decentralized structures set the stage for the evolution of an antitrust doctrine based upon the false premise that such structures should be treated differently from the traditional centralized administrative forms that preceded them.

\section{II}

FORMULATIONS OF THE INTRAENTERPRISE CONSPIRACY DOCTRINE

At issue in General Motors was whether and by what standard courts should find that multidivisional business enterprises contain the plurality of actors required for a section 1 conspiracy. While the court's finding of conspiracy resolved the first issue, ${ }^{31}$ the standard by which subsidiaries will be considered to be independent entities capable of conspiracy continues to be debated. Before examining the different formulations of that standard, it is helpful to identify the values protected by the antitrust laws and to consider what kind of standard is necessary to promote these interests.

\section{A. The Ideal Approach}

An ideal antitrust standard must maintain and encourage the competitive use of economic resources. ${ }^{32}$ While not controlled by the strictures of economic efficiency, ${ }^{33}$ section 1 indirectly ensures efficiency by promoting independent centers of production and imitiative essential for the rational allocation of resources. ${ }^{34}$ Similarly, a diversified corporation's use of a decentralized structure promotes the efficient allocation of resources ${ }^{35}$ because decisionmakers function in narrow areas of

31. The Supreme Court subsequently adopted the General Motors rule of intraenterprise capacity to conspire in United States v. Yellow Cab Co., 332 U.S. 218, 227 (1947).

32. C. KAYSEN \& D. TURNER, supra note 3, at $44-45$ (The primary goal of antitrust should be the protection of competitive processes by limiting market power.).

33. See generally L. Sullivan, supra note S, \& 1, at 5-7; Blake \& Jones, In Defense of Antitrust, 65 Colum. L. Rev. 377, 381-84 (1965); Bork \& Bowman, The Crisis in Antitrist, 65 Colum. L. REv. 363, 369-70 (1965).

34. See supra note 4 .

35. The benefits of decentralization accrue only so long as the corporation maintains a divi- 
their expertise.

A standard for determining when subsidiaries are sufficiently independent from their parents to be subject to intraenterprise conspiracy, therefore, should be structured to permit businesses to realize the efficiencies of decentralization, without betraying the basic goal of section 1: preserving coinpetition. Decentralization which results in subsidiaries with day-to-day authority, but insufficient long-term authority to be considered competitors, should be encouraged. A rule that exposes such enterprises to conspiracy liability encourages complex businesses to adopt a less efficient centralized structure in order to avoid liability. In contrast, parent corporations that abandon all control of their subdivisions should not be able to assert they remain a single entity when, in fact, the parent corporation has little or no authority over the subdivisions. The question remains, however, how to ascertain when the crucial degree of subdivision independence is present.

\section{B. The Supreme Court's Formalistic Approach}

\section{The Evolution of a Formalistic Standard}

The Supreme Court has applied the intraenterprise conspiracy doctrine in five cases. ${ }^{36}$ The first of these was United States v. Yellow $\mathrm{Cab} \mathrm{Co}^{37}$ In that case, the Government charged Morris Markin and six taxi manufacturing and operating corporations owned in part by him, ${ }^{38}$ with a conspiracy to restrain the market for the purchase of taxicabs. The Government asserted that interlocking agreements among the companies prevented the cab operating companies from purchasing their taxis from outside manufacturers. ${ }^{39}$ The Supreme Court upheld the charge against a motion to dismiss, stating: "The test of illegality

sion of operational and long-term stategic responsibility. If the parent delegates both operational decisions and long-term, policy-oriented decisions to its subsidiary, it loses the ability to control the nature and direction of the corporation's activities. Without any overall coordination among the counpany's parts, the parent is unable to secure the efficiency benefits of decentralization. See infra text accounpanying notes $120-25$.

36. See Perma Life Muffers, Inc. v. International Parts Corp., 392 U.S. 134 (1968); Timken Roller Bearing Co. v. United States, 341 U.S. 593 (1951); Kiefer-Stewart Co. v. Joseph E. Seagram \& Sons, Inc., 340 U.S. 211 (1951); Schine Claain Theatres, Inc. v. United States, 334 U.S. 110 (1948); United States v. Yellow Cab Co., 332 U.S. 218 (1947).

37. 332 U.S. 218 (1947).

38. The complex ownership arrangement of the Yellow Cab enterprise can be visualized as a pyramid, with Morris Markin at the top. He owned $100 \%$ of the stock of Cab Sales and Parts Corporation and a controlling interest in Checker Cab Manufacturing Corporation (CCM). Markin's associates controlled Checker Taxi Company. CCM lield $62 \%$ of the stock in Parmalee Transportation Company, which in turn owned a controlling interest in the Chicago Yellow Cab Company and $100 \%$ of several other cab operating companies. Id. at 221-22.

39. CCM's control excluded all other taxicab manufacturers from $100 \%$ of the Pittsburgh market, $86 \%$ of the Chicago unarket, $58 \%$ of the Minneapolis market, and $15 \%$ of the New York market. Id. at 224. 
under the [Sherman] Act is the presence or absence of an unreasonable restraint on interstate commerce. Such a restraimt may result as readily from a conspiracy among those who are affiliated or integrated under common ownership as from a conspiracy among those who are otherwise independent." $" 40$

Early the next year, the Court considered another case involving trade restraints effected by affiliated companies within a single enterprise. In Schine Chain Theatres, Inc. $\nu$. United States, ${ }^{41}$ the Court found that joint negotiations conducted by a parent and its wholly owned subsidiaries with inotion picture distributors lad illegally restrained trade. The enhanced bargaiming power derived from such a combination, the Court noted, enabled the defendants to cxact significantly better terms than could be secured by competing theater chains. "The concerted action of the parent coinpany, its subsidiaries, and the named officers and directors . . . was a conspiracy which was not iminunized by reason of the fact that the ineinbers were closely affiliated rather than independent." 42

It was apparent from the holdings in Yellow Cab and Schine that the Court's doctrime of intraenterprise conspiracy was an expansive one. The sweeping language of the Court's holdings and the widely varied facts of the two cases suggested no practical limit to the doctrime. While the Yellow $\mathrm{Cab}$ enterprise reseinbled an amalgam of loosely af-

40. Id. at 227. McQuade contends that the holding in Yellow Cab is more limited than this declaration suggests. He points out that the Yellow Cab opinion einphasized that the primary object behind the formation of the subsidiary network was to restrain trade. McQuade, supra note 4, at 194-95. Limiting Yellow $C a b$ to this narrow circumstance, however, is not viable in hight of the Court's decision one year later in Schine Chain Theatres, applying the language and holding of Yellow Cab to facts which did not suggest that the Schine enterprise formed its wholly owned subsidiaries for an anticounpetitive purpose. See Schine Chain Theatres, Inc. v. United States, 334 U.S. 110,116 (1948).

41. 334 U.S. 110 (1948).

42. Id. at 116. The language of the Schine opinion suggests that the majority intended to construct a rule of $\S 1$ liability that would loold officers and directors capable of conspiracy with the corporation or its subsidiaries. Cf. Note, supra note 7 , at $663 \mathrm{n} .10$ (the agreement among the corporate officers and directors did not form the basis for Schine's holding that there had been a $\S 1$ violation). The Fifth Circuit rejected this reading in Nelson Radio \& Supply Co. v. Motorola, Inc., 200 F.2d 911 (5th Cir. 1952), eert. denied, 345 U.S. 925 (1953). Relying on the basic primciple that conspiracy requires an agreement between two or more persons, the Fifth Circuit found that persons acting for the corporation were not, by definition, separate from it. This, the court reasoned, followed from the fact that "[t]he defendant is a corporate person and as such it can act only through its officers and representatives." Id. at 914 . Courts have generally adopted the $\mathrm{Nel}$ son limitation on $\S 1$ liability. See, e.g., Tose v. First Pa. Bank, 648 F.2d 879, $893-94$ (3d Cir), cert. denied, 454 U.S. 893 (1981); Card v. National Life Ins. Co., 603 F.2d 828, 834 (10th Cir. 1979); H. \& B. Equip. Co. v. International Harvester Co., 577 F.2d 239, 244 (5th Cir. 1978) (officers and enployees may be capable of conspiracy if they lave a personal financial stake in the conspiracy charged); Morton Bldgs. of Neb., Inc. v. Morton Bldgs., Inc., 531 F.2d 910, 916-17 (8th Cir. 1976); Cliapinan v. Rudd Paint \& Varnisli Co., 409 F.2d 635, 643 n.9 (9th Cir. 1969). 
filiated, independent companies, ${ }^{43}$ the Schine subsidiaries were wholly owned and centrally managed by the parent company. ${ }^{44}$ The implications were overwhelming. The two cases suggested that no enterprise with separately incorporated subdivisions would fall outside the reach of section 1 if its internal agreements restrained trade. The cases that followed did hittle to clarify the scope of the standard.

Kiefer-Stewart Co. v. Joseph E. Seagram \& Sons, Inc. ${ }^{45}$ dealt with a new form of intraenterprise conspiracy. There the Court held that sales subsidiaries of a smgle corporation could not jointly refuse to deal with a wholesaler who had refused to sell their products at the maximum retail price set by the parent company. ${ }^{46}$ The Court rejected Seagram's defense that its subdivisions acted inerely as "instrumentahties of a single manufacturing-merchandizing unit."47 A section 1 violation was particularly likely to be found, it noted, where the conspiring units held themselves out to be competitors. ${ }^{48}$ A later case suggests, however, that

43. See supra note 38 .

44. Two of the individual defendants, the Schine brothers, held the principal offices of both the parent corporation and the subsidiaries. They supervised the film distribution activities of the five operating subsidiaries. In addition, they were the principal stockholders in the parent corporation aud substantially controlled the subsidiaries as well. United States v. Schine Chain Theaters, Inc., 63 F. Supp. 229, 232 (W.D.N.Y. 1945), aff'd in part and rev'd in part, 334 U.S. 110 (1948).

45. 340 U.S. 211 (1951).

46. Id. at 214 .

47. Id. at 215. Instead, the Court invoked the broad holding of Yellow Cab, stating only that "common ownership and control does not liberate corporations from the impact of the antitrust laws." Id.

48. Id. Kiefer-Stewart's focus on intraenterprise competition las been criticized extensively. See, e.g., Handler \& Smart, supra note 4, at 53-55 (questioning the nexus between subsidiary competition and $\$ 1$ concerns); Note, supra note 7, at $667-69$ (noting Court's failure to provide practical guidelines for applying the coinpetition test, and also arguing that $\S 1$ should not be used in a way that penalizes coinpetition); Note, supra note 4 , at 734-35 (noting Court's failure to explain its willingness to enhance $\S$ I exposure where subsidiary competition is present and its failure to provide guidance for applying the standard). Additionally, it is apparent that competition would never be a relevant variable when the conspiracy alleged is between vertically related corporate units, simce even in the broadest sense of the word, they are not coinpetitors.

Despite its weaknesses, several lower courts consider intraenterprise competition a prerequisite for $\$ 1$ liability. See, e.g., Aaron E. Levine \& Co. v. Calkraft Paper Co., 429 F. Supp. 1039, 1043-44 (E.D. Mich. 1976); Call Carl, Inc. v. BP Oil Corp., 403 F. Supp. 568, 572-73 (D. Md. 1975), aff'd in part and rev'd in part on other grounds, 554 F.2d 623 (4th Cir.), cert. denied, 434 U.S. 923 (1977); Beckman v. Walter Kidde \& Co., 316 F. Supp. 1321, 1325-26 (E.D.N.Y. 1970), affd per curiam, 451 F.2d 593 (2d Cir. 1971), cert. denied, 408 U.S. 922 (1972).

On the other hand, several courts of appeals have rejected the notion that competition need be shown. See, e.g. , Battle v. Liberty Nat'l Life Ins. Co., 493 F.2d 39, 44 (5th Cir. 1974) ("While the existence of competition between [a parent and its subsidiary] would teud to estabhish their separateness ..., the absence of such competition does not preclude the existence of two separate organizations."), cert. denied, 419 U.S. 1110 (1975); George R. Whitten, Jr., Inc. v. Paddock Pool Builders, Inc., 508 F.2d 547, 557 (1st Cir. 1974), cert. denied, 421 U.S. 1004 (1975); see also Diehl \& Sons, Inc. v. International Harvester Co., 426 F. Supp. 110, 117 (E.D.N.Y. 1976).

The Ninth Circuit agrees that competition is not essential to a finding of intraenterprise liability, see William Inglis \& Sons Baking Co. v. ITT Continental Baking Co., 668 F.2d 1014, 1055 (9th Cir. 1981), cert. denied, 103 S. Ct. 57 (1982), and therefore treats it merely as one element in 
imtracorporate competition is not a requirement for intraenterprise liability. ${ }^{49}$ In the next case, the Court looked elsewhere in search of a test to imdicate when subdivisions of an enterprise would be subject to the sanctions of section 1 .

In Timken Roller Bearing Co. v. United States, ${ }^{50}$ the Government accused Timken, an American corporation, and two partly owncd foreign enterprises ${ }^{51}$ of restraining trade in the worldwide market for frictionless ball bearings. While the majority did not make explicit its reliance on the separate incorporation factor, ${ }^{52}$ Justice Jackson noted it in his dissent:

It is admitted that if Timken had . . . set up separate departments to operate plants in France and Great Britain . . . "that would not be a conspiracy" . . . because a corporation camiot conspire with itself. ... Thus, the Court applies the well-established conspiracy doctrine that what it would not be illegal for Timken to do alone may be illegal as a conspiracy when done by two legally separate persons. ${ }^{53}$

In Perma Life Mufflers, Inc. v. International Parts Corp., ${ }^{54}$ the most recent intraenterprise conspiracy case, the Court clearly relied upon

its multifactored analysis of conspiratorial capability, see, e.g., Las Vegas Sun, Inc. v. Summa Corp., 610 F.2d 614, 618 (9th Cir. 1979), cert. denied, 447 U.S. 906 (1980); Knutson v. Daily Review, Inc., 548 F.2d 795, 801-03 (9th Cir. 1976), cert. denied, 433 U.S. 910 (1977). For a description of the multifactored analysis, see infra text accompanying notes 78-100.

49. The record in Perma Life Muffiers, Inc. v. International Parts Corp., 392 U.S. 134 (1968), evidences a dispute between the parties as to whether or not International Parts and its sales subsidiary, Midas, Inc., sold competing exhaust systems or held themselves out as competitors. Handler, supra note 10, at 184-85. Justice Black, however, did not address this issue in his opinion. Commentators have characterized his omission as constituting a retreat from the Kiefer-Stewart competition limitation. See Handler, supra note 10, at 184-86; Comment, supra notc 10, at 73; Note, supra note 7, at $669 \mathrm{n} .42$. At most, intraenterprise competition would appear to be relevant only where the collusive conduct alleged has a special relationship to the existence of such competition. For instance, joint refusals to deal pose a threat of anti-coinpetitive effects only when the conspiring entities are competitors. "Common sense dictates the conclusion that where the alleged conspirators are not competitors in the marketplace . . . refusal to deal cannot result in the flessening of competition] which the Sherman Act was meant to combat." Aaron E. Levine \& Co.v. Calkraft Paper Co., 429 F.Supp. 1039, 1046 (E.D. Mich. 1976).

50. 341 U.S. 593 (1951).

51. Timken Roller Bearing Company (American Timken) acquired 30\% of the stock of its Enghish ball bearing licensee (British Timken). These two companies joimtly established French Timken, both holding $50 \%$ of the stock. British Timken managed this joint venture exclusively. All three firms, as part of their licensing agreement for the Timken-patented frictionless bearing, agreed to set prices, allocate sales territory and restrain outsiders from entering their designated markets. United States v. Timken Roller Bearing Co., 83 F. Supp. 284, 292-95 (N.D. Ohio 1949), aff' in part and modified in part, 341 U.S. 593 (1951).

52. The Court's only reference to separate incorporation was obscure: "[T]he fact that there is common ownership or control of the contracting corporatious does not liberate them from the impact of the antitrust laws. Nor . . [ [may] agreements betiveen legally separate persons and companies to supress competition . . . be justified by labeling the project a 'joint venture.' " 341 U.S. at 598 (citations omitted).

53. Id. at 606 (Jackson, J., dissenting).

54. 392 U.S. 134 (1968). 
separate incorporation as the standard for determining the capacity of a corporate subdivision to conspire with other subdivisions or with the parent. The Court held that the defendants' franchise agreement requiring Midas Muffer franchisees to purchase all of their muffler and exhaust systems from International Parts' marketmg subsidiary violated section 1. Rejecting the argument that meinbers of a single corporate family should be exempt from the sanctions of section 1 , the Court stated: "[S]ince respondents Midas and International availed themselves of the privilege of doing business through separate corporations, the fact of common ownership could not save them from any of the obligations that the law imposes on separate entities." 55

The most troublesome aspect of these cases, taken together, is their nonanalytic approach to determining intraenterprise conspiracy liability. The Court has never articulated the antitrust rationales underlying its doctrine. ${ }^{56}$ The wide range of factual settings in which the Court

55. Id. at 141-42 (citing United States v. Timken Roller Bearing Co., 341 U.S. 593, 598 (1951), and United States v. Yellow Cab Co., 332 U.S. 218, 227 (1947)). As noted by one commentator, Justice Black's position "echoed the Seventh Circuit's analysis a quarter of a century before in United States v. General Motors." Handler \& Smart, supra note 4, at 34. Interestingly, the Seventh Circuit had granted summary judgment below in favor of Midas and International and ignored General Motors in holding that the defendants were part of a single busmess entity. 376 F.2d 692, 693 (7th Cir. 1967), rev'd, 392 U.S. 134 (1968).

Commentators have noted the Court's apparent discomfort with such a broad rule of hability, observing specifically Justice Black's next sentence in the Perma Life opinion: "In any event each petitioner can clearly charge [in the alternative] a combination between Midas and limself, as of the day he unwillingly comphed with the restrictive franchise agreements." See Handler \& Smart, supra note 4, at 34 (quoting Perma Life, 392 U.S. at 142, and arguing that the intraenterprise conspiracy holding was unnecessary); Kempf, supra note 7, at 176; Note, supra note 4, at 725-26.

Commentators have also asserted that Perma Life is inconsistent with the Court's 1962 opmion in Sunkist Growers, Inc. v. Winkler \& Smith Citrns Prods. Co., 370 U.S. 19 (1962). In that case, the Court appeared to concentrate on the substance and economic significance of the parentsubsidiary relationship, rather than on the inere fact of separate imcorporation. Handler \& Smart, supra note 4, at 35 n.62; Note, supra note 4, at 729-30. Sunkist, however, should not be construed as an intraenterprise conspiracy case since it addressed only the issue of whether joint marketing organizations are protected under $\$ 6$ of the Clayton Act (the Capper-Volsted agricultural exemption). See Sunkist, 370 U.S. at 27; accord Columbia Metal Culvert Co. v. Kaiser Aluminum \& Chem. Corp., 579 F.2d 20, 33-34 n,49 (3d Cir.), cert. denied, 439 U.S. 876 (1978); cf. Comment, supra note 10, at 71-72 (Court's holding was not restricted to Capper-Volsted organizations).

56. See McQuade, supra note 4, at 188 . One scholar lias noted that in each case, there was at least one alternative basis for finding an antitrust violation by the defendant. Note, supra note 4, at 726-27. But see Handler \& Smart, supra note 4, at $26 \mathrm{n} .16$ (suggesting that the intraenterprise conspiracy doctrine might have been necessary to establisl liability in Kiefer-Stewart). The identification of alternative grounds suggests that the Court may be uncoinfortable relying exclusively on its broadly stated rule of intraenterprise conspiracy. At a minimum, the availability of other bases of liability contributes to the absence of analytic rigor in the Court's opinions. See McQuade, supra note 4, at 188; Note, supra note 4, at 718.

The reaction of the antitrust authorities to the Court's broad doctrine of intraenterprise liability has been widespread nonenforcement. The Department of Justice has never brought a $\$ 1$ action against a parent and its subsidiary charging only an intraenterprise conspiracy. Handler \& Smart, supra note 4, at 49-50 \& n.128. Nor has the FTC, with the exception of two early actions, filed a coinplaint that rehes upon the broad doctrine. Id. at 66-67 \& n.208. 
has applied the doctrine and the vague language of the opinions ${ }^{57}$ make it difficult for lower courts to ascertain the law or to discern its possible limits. Frustrated by the vague contours of the Supreme Court's opinions, lower courts have attempted to distill from the fact patterns of the cases implicit doctrinal limitations in the Court's concept of a "single entity." 58 Only one rule can be identified witl any certainty: corporate subdivisions that are incorporated separately are considered independent enough to conspire with their parent or with each other. ${ }^{59}$

Lower courts have extended the Supreine Court's formalistic presuinption that separate incorporation is an accurate index of a subdivision's independence. In Joseph E. Seagram \& Sons, Inc. v. Hawaiian Oke \& Liquors, Ltd. ${ }^{60}$ the Ninth Circuit, applying the obverse of Perma Life's separate incorporation test, held that, as a inatter of law, unincorporated subdivisions are not capable of conspiring among themselves or with the parent corporation. ${ }^{61}$ Combined with the Supreme Court precedent, these holdings make separate incorporation a minimum requirement before subdivisions will be treated as separate

57. See Handler \& Smart, supra note 4, at 38; Kempf, supra note 7, at 176; Willis \& Pitofsky, supra note 7 , at 24.

58. See, e.g., Willis \& Pitofsky, supra note 7, at 36-38 (the competition limitation and the abuse of subsidiary limitation); ATTORNEY GENERAL's REPORT, supra note 5, at 34 (internal decision limitation).

59. Although some circuits require additional indicia of independence before they will find intraenterprise conspiracy, see infra text accompanying notes 78-100, the First, Third, and Fiftl Circuits apply the Supreme Court's standard literally-the fact of separate incorporation is conclusive evidence of a subsidiary's capacity to conspire, see, e.g., H. \& B. Equip. Co. v. International Harvester Co., 577 F.2d 239, 245 (5th Cir. 1978) (dicta) ("The parent's choice of form is important. Having availed itself of separate mcorporation for [its subsidiary] HARCO, International Harvester marked it off as a distmct entity, and the antitrust laws treat it as such."); Columbia Metal Culvert Co. v. Kaiser Aluminum \& Chem. Corp., 579 F.2d 20, 34 n.49 (3d Cir.) ("[T]he Supreme Court has made clear that the choice to adopt dual corporate form subjects busimesses to the strictures of the antitrust laws."), cert. denied, 439 U.S. 876 (1978); Cromar Co. v. Nuclear Materials Equip. Corp., 543 F.2d 501, $511-12$ (3d Cir. 1976); George R. Whitten, Jr., Inc. v. Paddock Pool Builders, Inc., 508 F.2d 547, 557 (Ist Cir. 1974), cert. denied, 42I U.S. 1004 (1975). See also Battle v. Liberty Nat'l Life Ins. Co., 493 F.2d 39, 44-45 (5th Cir. 1974) (holding without analysis that a burial imsurance company and its separately incorporated funeral loome service could conspire), cert. denied, 419 U.S. 1110 (1975).

60. 416 F.2d 71 (9th Cir. 1969), cert. denied, 396 U.S. 1062 (1970).

61. Id. at 83-84. A later passage from Hawaiian Oke suggests that the true factor behind the Nimth Circuit's reluctance to impose antitrust liability on the Seagram divisions was the court's fear of the impact that intracorporate conspiracy liability might have on the efficient administration of business: "No corporation of any size can operate without . . . internal division[s] . . . . [S]ound management demands extensive delegation of authority within the organization." 416 F.2d at 83. Having acknowledged the economic indispensability of corporate subdivisions, however, the court then granted them a per se immunity based on its belief that "there [was] no logical or practical way to avoid holding that all intra-corporate agreements are or may be found to be conspiracies in restraint of trade." Id. at 84 . It is interesting to contrast this reasoning with the Ninth Circuit's later insistence on finding a way to distinguish among separately incorporated subsidiaries entering into agreements that restrain trade. See infra text accompanying notes 78-94. 
entities in applying section $1 .^{62}$

\section{Criticism of the Formalistic Doctrine}

The primary weakness of the Court's formahstic separate incorporation standard hes in its failure to measure the essential factor upon which the doctrine of intraenterprise conspiracy should rest-whether the subsidiary is an independent center of initiative that, absent internal agreements, would be able to compete with the parent corporation. Critics of the Supreme Court doctrine have largely agreed that rehance on the incident of separate incorporation as a basis for antitrust hability "places too much weight on labels,"63 exalting form over substance ${ }^{64}$ in contravention of the Court's earlier directive in Yellow $\mathrm{Cab} .^{65}$

The decision to incorporate a subsidiary separately may indeed reflect an intention to create an independent operational division. Businesses, however, may reach the same decision for entirely unrelated reasons. Historically, tax advantages created a major inupetus for separate incorporation of subsidiaries. ${ }^{66}$ Separate imcorporation may allow a parent to preserve the goodwill associated with a subsidiary's name, ${ }^{67}$ to improve the marketability or transferability of subsidiary stock, ${ }^{68}$ to avoid regulations discriminatimg against foreign corporations, ${ }^{69}$ to tailor accounting and financial systems to ineet a subsidiary's specialized operating needs, ${ }^{70}$ or to mamtam separate employee benefit and wage plans in each operating unit. ${ }^{71}$

By making separate incorporation a factor in determining antitrust hability, therefore, the formalistic standard penalizes enterprises that separately mcorporate their divisions for legitimate reasons. The stan-

62. See, e.g. , H. \& B. Equip. Co. v. International Harvester Co., 577 F.2d 239, 244 (5th Cir. 1978); Aaron E. Levine \& Co. v. Calkraft Paper Co., 429 F. Supp. 1039, 1043 (E.D. Mich. 1976); Diehl \& Sons, Inc. v. International Harvester Co., 426 F. Supp. 110, 118 (E.D.N.Y. 1976); see also infra text accompanying note 79.

63. Timken Roller Bearing Co. v. United States, 341 U.S. 593, 606-07 (1951) (Jackson, J., dissentimg).

64. Ogilvie v. Fotomat Corp., 641 F.2d 581, 588 (8th Cir. 1981); Handler \& Smart, supra note 4 , at 44,72 ; Note, supra note 4 , at 727-29.

65. See 332 U.S. at 227 ("[The Sherman Act] is aimed at substance rather than form.").

66. Wilberding, An Ominous Warning for Antitust Law: The Disposition of the "Bathtub" Conspiracy-As Applied to Unincorporated Divisions-May Have Left a Tell-Tale Ring Around the $T u b, 32$ Oнго ST. L.J. 43, 47-48 (1971). Congress has largely eliminated such incentives by amending the Internal Reveuue Code. Note, supra note 7, at 668 n.36.

67. Note, supra note 7, at 668 n.36; Note, supra note 4, at 728.

68. Note, supra note 4 , at 728.

69. Willis \& Pitofsky, supra note 7, at 28; see also Timken Roller Bearing Co. v. United States, 341 U.S. 593, 606-07 (1951) (Jackson, J., dissenting).

70. Willis \& Pitofsky, supra note 7 , at 27.

71. See, e.g., Photovest Corp. v. Fotomat Corp., 606 F.2d 704, 726 (7th Cir. 1979), cert. denied, 445 U.S. 917 (1980). 
dard's concomitant recognition of a "safe harbor" for unincorporated subdivisions creates an incentive for businesses to deincorporate their subsidiaries in order to avoid antitrust hability. In this way, business executives may feel compelled to sacrifice the legitimate advantages that separate incorporation allows. Furthermore, separate incorporation indicates very little about the degree of true imdependence held by subsidiaries.

Where separately imcorporated subsidiaries do not function independently froin the parent company, the imposition of intraenterprise conspiracy liability works to create a new rule of liability for single firm restraints of trade. The statutory sanctions of section 1, unlike those of section 2, are not intended to reach single firm conduct. ${ }^{72}$ In its present form, therefore, the intraenterprise conspiracy doctrime allows plaintiffs to attack essentially unilateral conduct that, for lack of some element like market power, does not meet the threshold requirements of a section 2 offense. ${ }^{73}$

The final weakness of the formahistic doctrine is its susceptibility to manipulation by defendants intent on avoiding antitrust hability. This pitfall is aptly demonstrated by the different results reached in Kiefer-Stewart and Hawaiian Oke. Both cases concerned allegations of a conspiracy to restrain trade stemming from decisions made by Seagram's sales divisions to terminate the plaintiffs' distributorships. ${ }^{74}$ Seagram's management structure and operations had changed little in the intervening years. ${ }^{75}$ In Kiefer-Stewart, the Supreme Court held that Seagram's separately incorporated subdivisions had violated section 1. ${ }^{76}$ Seagram deincorporated its subdivisions, lowever, before the $\mathrm{Ha}$ waiian Oke controversy arose. In that case, the court held that unincorporated divisions were incapable of section 1 conspiracy. ${ }^{77}$ This example demonstrates how a fornalistic approach allows liability for similar conduct by corporate subdivisions to turn solely on whether they are incorporated. To escape hability a parent company need only demcorporate its subsidiaries.

72. See supra note 6.

73. See Handler \& Smart, supra note 4, at 67; see also Note, supra note 4, at 737.

74. See Kiefer-Stewart Co. v. Joseph E. Seagram \& Sons, Inc., 340 U.S. 211, 213 (1951) (Seagram and Calvert refused to sell to wholesaler); Joseph E. Seagram \& Sons, Inc. v. Hawaiian Oke \& Liquors, Ltd., 416 F.2d 71, 74 (9th Cir. 1969) (Calvert, Four Roses, and Frankfort refused to renew wholesale contract), cert. denied, 396 U.S. 1062 (1970).

75. Hawä̈an Oke \& Liquors, Ltd. v. Joseph E. Seagram \& Sons, Inc., 272 F. Supp. 915,921 (D. Hawaii 1967), rev'd, 416 F.2d 71 (9th Cir. 1969), cert. denied, 396 U.S. 1062 (1970). See also Kempf, stpra note 7 , at 178.

76. 340 U.S. at 211.

77. 272 F. Supp. at 924 . 


\section{Circuit Court Development of a Functional Standard}

Disenchanted with the formalistic reasoning that has dominated the Supreme Court's intraenterprise conspiracy doctrine, commentators and courts have begun to reassess the doctrine and to formulate a standard that better conforms to the realities of the business world. Since Hawaiian Oke, the Ninth Circuit has developed an elaborate refinement of the Supreme Court's intraenterprise conspiracy doctrine. At its foundation is the proposition that a subsidiary's status as a separate corporation should not conclusively determine whether it is capable of antitrust conspiracy. ${ }^{78}$

The Ninth Circuit has formulated a novel two-tiered approach to intraenterprise conspiracy. First, the court inquires whether the subdivision is separately incorporated. If it is not, then the enterprise is held mcapable of conspiracy as a matter of law ${ }^{79}$ If, however, the parent has separately incorporated its subsidiary, the court will apply a second test to see whether they are so functionally related as to constitute a single entity. This functional standard focuses on the practical interrelatedness of the separately incorporated subsidiaries in order to determime "when there is enough separation between [allegedly conspiring] entities to make treating them as two independent actors sensible."80

\section{Emergence of the Functional Standard}

The first case to suggest a functional limitation to the Supreme Court's separate incorporation standard was Knutson v. Daily Review, Inc. ${ }^{81}$ The defendants in that case, a parent coinpany (DRI) and its separately incorporated, wholly owned subsidiary (BAPCO), operated and published five newspapers. Following labor disputes in 1973, DRI and BAPCO decided to replace their independent distributors with employee distributors who would sell the companies' newspapers directly to news carriers. The independent distributors sued to block the action, alleging a conspiracy in restraint of trade between the parent and its subsidiary.

Examining their relationship, the court found that although DRI

78. See, e.g., Thomsen v. Western Elec. Co., 680 F.2d 1263, 1266 (9th Cir.), cert. denied, 103 S. Ct. 348 (1982); William Inglis \& Sons Baking Co. v. ITT Continental Baking Co., 668 F.2d 1014, 1054 (9th Cir. 1981), cert. denied, 103 S. Ct. 57 (1982); Harvey v. Fearless Farris Wholesale, Inc., 589 F.2d 451, 455-56 (9th Cir. 1979); Knutson v. Daily Review, Inc., 548 F.2d 795, 802 (9th Cir. 1976), cert. denied, 433 U.S. 910 (1977).

79. See Joseph E. Seagram \& Sons, Inc. v. Hawaiian Oke \& Liquors, Ltd., 416 F.2d 71, 8384 (9th Cir. 1969), cert. denied, 396 U.S. 1062 (1970); supra text accompanying notes 60-61.

80. Independence Tube Corp. v. Copperweld Corp., 691 F.2d 310, 318 (7th Cir. 1982) (employing the Ninth Circuit's functional analysis), cert. granted, 103 S. Ct. 3109 (1983) (No. 821260).

81. 548 F.2d 795 (9th Cir. 1976), cert. denied, 433 U.S. 910 (1977). 
and BAPCO were separately incorporated, they formed a unified structure. "The relationship between thein far exceeds DRI's mere ownership of the subsidiary's stock, and therefore, this is not a case of parent and independent subsidiary, but of a smgle busmess unit separated only by the technicality of separate incorporation." 82 The Ninth Circuit, therefore, read the Supreme Court cases to say that while parents and their subsidiaries may be able to conspire, separate incorporation does not by itself establish conspiratorial capacity. Separate incorporation is a prerequisite but not a determining factor in the analysis. ${ }^{83}$

In the Ninth Circuit the capacity of two entities to conspire is a factual question. ${ }^{84}$ Separate incorporation militates against finding a single entity, but this factor can be outweighed by others demonstrating corporate integration. In Knutson, the fact that a single individual was the controlling shareholder of the parent coinpany, as well as the president of both corporations and the pubhsher of all five newspapers, weighed strongly in favor of characterizing DRI and BAPCO as a single entity. ${ }^{85}$ Also important were the degree of cooperative production among the papers, ${ }^{86}$ and the fact that the papers did not hold themselves out as competitors. ${ }^{87}$

Other decisions by the Ninth Circuit have expanded the hist of relevant factors to include: shared business solicitation, ${ }^{88}$ joint labor ne-

82. Id. at 802 .

83. Id.; see also Thomsen v. Western Elec. Co., 680 F.2d 1263, 1266 (9th Cir.), cert. denied, 103 S. Ct. 348 (1982); Mntual Fund Investors, Inc. v. Putnam Management Co., 553 F.2d 620, 626 (9th Cir. 1977).

84. Knutson v. Daily Review, Inc., 548 F.2d 795, 802 (9th Cir. 1976), cert. denied, 433 U.S. 910 (1977); see also Thomsen v. Western Elec. Co., 680 F.2d 1263, 1266 (9th Cir.), cert. denied, 103 S. Ct. 348 (1982).

85. 548 F.2d at 802. Other Ninth Circuit cases have held that when onc individual owns and controls the activities of both the parent and the subsidiary companies, the subdivision cannot function independently of the parent corporation. See Las Vegas Sun, Inc. v. Summa Corp., 610 F.2d 614, 618 (9th Cir. 1979), cert. denied, 447 U.S. 906 (1980); Harvey v. Fearless Farris Wholesale, Inc., 589 F.2d 451, 457 (9th Cir. 1979); Las Vegas Drive-In Theatre, Inc. v. National Gen. Theatres, Inc., 1979-2 Trade Cas. (CCH) I 62,895, at 79,184 (9th Cir. 1979); see also Murphy Tugboat Co. v. Crowley, 658 F.2d 1256 (9th Cir. 1981) (citing the subsidiaries' separate managements as a factor supporting the conclusion that the subsidiaries were capable of conspiring), cert. denied, 455 U.S. 1018 (1982). For a complete discussion of the "sole decisionmaker" rnle and its shortcomings, see Handler \& Smart, supra note 4, at 46-49.

86. The two companies shared persounel, and all three daily papers published the same sports page, financial section, and television $\log$, and printed substantially the same news stories and advertisements. The papers also shared composing facilities. The high degree of production integration amply supported a finding that the parent and subsidiary were a single business unit. Knutson, 548 F.2d at 802 .

87. Id.; see supra note 48 and accompanying text.

88. Las Vegas Sun, Inc. v. Sumina Corp., 610 F.2d 614, 618 (9th Cir. 1979), cert. denied, 447 U.S. 906 (1980); see Murphy Tugboat Co. v. Shipowners \& Merchants Towboat Co., 467 F. Supp. 841,859 (N.D. Cal. 1979), aff'd sub nom. Murphy Tugboat Co. v. Crowley, 658 F.2d 1256 (9th Cir. 1981), cert. denied, 455 U.S. 1018 (1982). 
gotiations, ${ }^{89}$ shared locations, ${ }^{90}$ consolidated corporate tax returns, ${ }^{91}$ common corporate logo, ${ }^{92}$ shared research and development resources, ${ }^{93}$ and intraenterprise exchange of personnel..$^{94}$

The Seventh and Eighth Circuits have adopted the functional analysis. ${ }^{95}$ One recent Seventh Circuit intraenterprise conspiracy case that applied this approach was Independence Tube Corp. v. Copperweld Corp. ${ }^{96}$ There, the court of appeals affirmed a judgment agamst Copperweld and its recently acquired, wholly owned subsidiary Regal, holding that their attempts to prevent the plaintiff from entering the steel tubing market violated section 1 .

In determining that the jury was justified in finding the parent and subsidiary sufficiently imdependent to conspire, the court cited testimony evidencing Copperweld's intention to maintain Regal's independent operating status after acquiring the subsidiary, and the absence of any imtegration of the subsidiary into the parent's operations. ${ }^{97}$ In addition, evidence was presented that Regal manageinent

89. Thomsen v. Western Elec. Co., 680 F.2d 1263, 1267 (9th Cir.), cert. denied, 103 S. Ct. 348 (1982); Murphy Tugboat Co. v. Shipowners \& Merchants Towboat Co., 467 F. Supp. 841, 859 (N.D. Cal. 1979), affd sub nom. Murphy Tugboat Co. v. Crowley, 658 F.2d 1256 (9th Cir. 1981), cert. denied, 455 U.S. 1018 (1982).

90. See Murphy Tugboat Co. v. Shipowners \& Merchants Towboat Co., 467 F. Supp. 841, 859 (N.D. Cal. 1979), affd sub nom. Murphy Tugboat Co. v. Crowley, 658 F.2d 1256 (9th Cir. 1981), cert. denied, 455 U.S. 1018 (1982). (1982).

91. Thomsen v. Westem Elec. Co., 680 F.2d 1263, 1266 (9th Cir.), cert. denied, 103 S. Ct. 348

92. Id. at 1267.

93. Id. at $1266-67$.

94. Id. at 1267; Los Angeles Memorial Coliseum Comm'n v. National Football League, 519 F. Supp. 581, 583 n.1 (C.D. Cal. 1981), appeal docketed, No. 83-5907 (9th Cir. May 24, 1983).

95. The Seventh Circuit adopted the Knutson functional test in Photovest Corp. v. Fotomat Corp., 606 F.2d 704 (7th Cir. 1979), cert. denied, 445 U.S. 917 (1980). The Eighth Circuit followed two years later in a similar case, Ogilvie v. Fotomat Corp., 641 F.2d 581 (8th Cir. 1981). In both cases, the plaintiff alleged that Fotomat Corporation and its wholly owned processing subsidiary, Fotomat Labs, Inc., colluded in a series of agreements to eliminate competition from franchised Fotomat retail outlets.

Citing the need to decide each case on its particular facts, Photovest, 606 F.2d at 726; Ogilvie, 641 F.2d at 589, the Seveuth and Eighth Circuits looked at a variety of factors in reaching their conclusion that the parent and its subsidiary were not separate entities capable of $\$ 1$ conspiracy. Facts found relevant by the Seveuth Circuit included: (1) Fotomat Labs was incorporated separately only to avoid labor unrest due to the differential benefits offered by the parent and its subsidiary; (2) Labs did not maintain separate corporate offices; (3) profit-sharing compensation for all Fotomat employees was based solely on the parent coinpany's profitability; (4) Fotomat consolidated all of its financial statements and tax returns; and (5) the historical purpose of the subsidiary was to act solely as a processing division for Fotomat Corporation and not as an independent processing facility. Photovest, 606 F.2d at 726-27. Undoubtedly influenced by the similarity of the Ogilvie facts to those of Photovest, the Eighth Circuit considered many of the same factors, adding only that the corporate officers of Fotomat had always served as the officers of Fotomat Labs. Ogilvie, 641 F.2d at 589.

96. 691 F.2d 310 (7th Cir. 1982), cert. granted, 103 S. Ct. 3109 (1983) (No. 82-1260).

97. Id. at 320 . 
enjoyed real autonomy im both day-to-day and long-term decisionmaking. ${ }^{8}$ Finally, the court noted that Regal and Copperweld had separate revenues, profit-sharing plans, sales forces, customers and suppliers. ${ }^{99}$ Taken together, the court held, these facts adequately supported the jury's finding that Regal was inore like an independent corporate entity than "merely a service arm" or division of its parent company. ${ }^{100}$

The Supreme Court's grant of certiorari in Copperweld presents the Court witl a clear opportunity to denounce, accept, or modify the functional approach to intraenterprise liability under section 1 . This Comment, therefore, turns to the strengths and weaknesses of the analysis advocated by Knutson and Copperweld.

\section{Strengths and Shortcomings of the Current Functional Standard}

Knutson and the cases following its example present a valuable but not problem-free alternative to the overinclusive and formalistie analysis advocated by earlier Supreme Court cases. Functional analysis represents a major analytic improvement over separate incorporation as a means of identifying independent entities capable of collusion under section 1. By focusing on factual indicia of subsidiary autonomy to measure the separateness of intraenterprise actors, courts can more accurately determine whether the corporate units actually function as two entities or as a single, integrated enterprise incapable of conspiracy.

The second major advantage of the functional approach is its resistance to easy manipulation by corporate defendants. In contrast to a separate incorporation test which, as the two Seagram cases demonstrate, can be avoided simply by deincorporation, the functional approach focuses on both the past and current conduct of a parent and its subsidiary. ${ }^{101}$ The "record" of perfomance on which the court's appraisal will rely is establislied long before the prospect of litigation surfaces. A corporation, sensing antitrust exposure, nay alter the relationship between the parent and its subsidiaries. Such action, however, would require that the operating relationships within the enterprise be restructured-certainly a nore formidable task than a paper reorganization. ${ }^{102}$

The functional approach of Knutson and Copperweld, however, is not without its own shortcomings. To start with, courts adhermg to the

\footnotetext{
98. $1 d$.

99. Id.

100. Id.

101. See, e.g, Ogilvie, 641 F.2d at 589 (considering the fact that Fotomat's corporate officers had always served as the officers of the Fotomat Labs subsidiary).

102. See supra text accompanying notes 74-77.
} 
functional standard have neglected to justify the factors they recognize as evidencing corporate autonomy or imtegration or to come to grips with their ambiguities. ${ }^{103}$ For instance, the use by a parent and its subsidiaries of unified labor negotiations has been relied upon twice as an indication of intraenterprise unity, ${ }^{104}$ apparently on the theory that enterprise-wide labor negotiation evidences a lack of subsidiary autonouny. Such reasoning, however, ignores equally plausible possibilities. The corporations may simply desire to achieve administrative efficiency or to exert inaximun economic pressure at the bargaining table by presenting a umited front. Similarly, the shared use of a logo does not necessarily reflect integration. Very loosely related companies could find it advantageous to be associated with each other in name or by logo, but be independent from each other im all other respects. ${ }^{105}$ In short, considerations of dubious relevance may find their way into the analysis, thereby distorting the result.

A second source of uncertamty is the courts' failure to almounce which of the identified factors are most important to their functional analysis. Factfinders seeking to employ this approacl ${ }^{106}$ are faced with an undifferentiated, unranked hist of disparate eleinents presented as relevant to the issue of corporate integration. The possibility of jury confusion and conflicting results is substantial. ${ }^{107}$ As shown by the

103. As one district court in the Ninth Circuit has coinplained, "The Ninth Circuit cases . . . accept the intraenterprise conspiracy theory but provide little analysis for the rule [nor do they] define the scope of its application." Island Tobacco Co. v. R.J. Reynolds Indus., 513 F. Supp. 726, 740 n.21 (D. Hawä̈ 1981).

104. See supra note 89.

105. See, e.g., Timken Roller Bearing Co. v. United States, 341 U.S. 593, 595-97 (1951) (facts revealed that although the eompanies shared the trademark "Timken," they were essentially independent); see also infra text accompanying notes 123-24.

106. As Handler \& Smart note, there remains some question about what role the jury is to play in determining whether a parent and its subsidiary are capable of conspiracy under $\S 1$. Handler \& Smart, supra note 4, at 60-61; see Murray v. Toyota Motor Distribs., Inc., 664 F.2d 1377,1379 (9th Cir.) (issue of whether a defendant is a simgle entity is a question of fact and should be reserved for jury determination), cert. denied, 457 U.S. 1106 (1982); Hunt-Wesson Foods, Inc. v. Ragu Foods, Inc., 627 F.2d 919, 927 n.5 (9th Cir. 1980) (resolution of intraenterprise conspiracy hinges on particular facts and is not suited to resolution on the face of the coinplaint), cert. denied, 450 U.S. 921 (1981). But see William Inglis \& Sons Baking Co. v. ITT Continental Baking Co., 668 F.2d 1014, 1055 (9th Cir. 1981) (additional facts concerning subsidiary's operatmg autonomy needed before summary judgment could be properly considered), cert. denied, 103 S. Ct. 57 (1982); see also Murphy Tugboat Co. v. Shipowners \& Merchants Towboat Co., 467 F. Supp. 841,859 n.15 (N.D. Cal. 1979) (capacity issue submitted to the jury, but on reflection it is more properly resolved by the eourt), affd sub nom. Murphy Tugboat Co. v. Crowley, 658 F.2d 1256 (9th Cir. 1981), cert. denied, 455 U.S. 1018 (1982).

107. See Independence Tube Corp. v. Copperweld Corp., 691 F.2d 310, 319 n.13 (instructions challenged by defendants as prejudicial since they allowed jury to consider irrelevant factors), cert. granted, 103 U.S. 3109 (1983) (No. 82-1260); Murply Tugboat Co. v. Shipowners \& Merchants Towboat Co., 467 F. Snpp. 841,859 n.15 (N.D. Cal. 1979) (noting jury's "great difficulty" in dealing with intraenterprise capacity issue), affd sub nom. Murphy Tugboat Co. v. Crowley, 658 
cases summarized above, no set of principles has yet emerged to guide factfinders in evaluatimg the probative worth of each of the many factors. They are free, as a result, to determine in an ad hoc fashion the weight to be accorded each factor.

The implications of this unpredictability are serious. Multicorporate enterprises attempting to conduct their business affairs within the confines of the Sherinan Act will find it difficult to assess what conditions they must meet to avoid imtraenterprise habihity. This uncertainty may discourage corporations froin adopting decentralized structures out of fear of the consequences endured by companies found to have violated section $1 .{ }^{108}$

The most profound criticism of functional analysis is that a parent's delegation of operational autonomy to its incorporated subsidiary exposes the corporation to the possibility of an antitrust lawsuit. ${ }^{109}$ In this way, it penalizes those diversified enterprises that require decentralized decisionmaking. A functional test fails to recognize that, im order to operate efficiently, subsidiaries must be given autonomy im their day-to-day operations. The decentralization of decisionmaking responsibility imto lower level operating units may be stymied by a rule of antitrust hability that commends instead closely controlled subsidiary operations. The mevitable result is a loss of managerial expertise and economic efficiency. ${ }^{110}$

What then is the correct outcome? The Supreme Court's standard-overinclusive, easily manipulated and imsensitive to antitrust concerns-is an unsatisfactory alternative. The functional approach also falls short of the ideal standard. Its chaotic treatment of factors provides little guidance to busmessmen or to the courts. In addition, it discourages corporate enterprises from adopting the decentralized structures necessary to administer diversified busmess activities effec-

F.2d 1256 (9th Cir. 1981), cert. denied, 455 U.S. 1018 (1982). See also Handler \& Smart, supra note 4 , at 61 .

108. The most serious consequence of a $\$ 1$ violation is the treble damage liability that accompanies private actions. See Handler \& Smart, supra note 4, at 67 (intraenterprise conspiracy doctrine is used principally by private plaintiffs because it is easier to prove a $\$ 1$ violation than to prove actual or attempted monopolization by a single firm under \& 2); see also McQuade, supra note 4 , at $184-85$.

Since $\S 1$ of the Shernan Act carries a threat of criminal sanctions, it is also possible that an intraenterprise conspiracy could subject individual officers to criminal penalties and the corporate entities to large fines. Such sanctions are unlikely, however, given the Justice Department's reluctance to prosecute a conspiracy based solely upon an intraenterprise agreemeut. See supra note 56.

109. It is ironic that the Ninth Circuit's functional test creates the very situation that the saine court criticized in Hawaïan Oke: "[U]nder the trial court's ruling, the more [sound and efficient the] delegation . . ., the more danger there will be that the holders of sucls delegated authority will be found by a court to be capable of [conspiracy] . . ." 416 F.2d at 83-84.

110. See supra text accompanying notes $23-25$. 
tively and efficiently. Part III presents an approach that responds to both the economic demands that created multicorporate business structures and the fundamental interests protected by section 1 of the Sherman Act.

\section{III}

\section{Choosing a More Appropriate Standard}

The formalistic and functional standards of intraenterprise conspiracy represent attempts to determine whether an enterprise contains the plurality of actors required for section 1 hability. The weaknesses of those approaches, as outlined in Part II, guide the search for a better standard. Four qualities emerge as desirable features.

First, the standard should be sensitive to the basic antitrust concern embodied in section 1-the promotion of independent centers of initiative. As suggested by the ideal nodel presented earlier, ${ }^{111}$ intraenterprise conspiracy doctrime should be reserved for those circumstances where the subdivision is an independent entity that functions essentially as a separate business. The standard employed must be able to distinguish between those subdivisions that are actually independent and those that are not. If nonautonoinous subsidiaries can be reached under the test, as they can be under the Supreme Court's separate incorporation standard, intraenterprise conspiracy becomes a tool to punish what are actually single firm restraints of trade. ${ }^{112}$ Such a result contravenes the plurality of actors requirenent of section 1 and does nothing to promote independent centers of initiative.

Second, the standard should reflect an understanding of nodern business structures-both the purposes they promote and the forces that shape them. Intraenterprise conspiracy doctrime should permit some degree of subdivision autonomy to allow business enterprises to function efficiently. ${ }^{113}$ The goal, therefore, is to develop a measure of subsidiary autonomy that can detect those situations when subdivisions really are imdependent entities, without discouraging the use of quasiautonomous subumits within a decentralized structure.

The third quality that the standard should possess is resistance to manipulation by businesses seeking to avoid antitrust liability. Fimally, to promote certainty, the test should be coherent and simple to apply.

\section{A. The Proposed Standard: A Decisionmaking Model}

This Comment recommends that courts look to the pattern of deci-

111. See supra text accompanying note 34 .

112. See supra text accompanying notes 6 \& 73.

113. See supra text accompanying note 35 . 
sionmaking within a business in order to determine when corporate subunits are independent entities. The basic function of any administrative structure is to process information and to make business decisions. ${ }^{114}$ Decisions that inust be made include both long-range decisions concerning the overall direction and developinent of the enterprise, and short-term decisions necessary to resolve the myriad probleins that arise in the company's day-to-day functioning. No business can operate without inanageinent inaking both kinds of decisions.

Subunits that possess sufficient authority to make their own longterm policy decisions sliould be deemed independent centers of mitiative and treated as separate entities under section 1 . Since they are not constrained by the parent company eithcr in their daily activities or im their long-term planning, these subunits are truly separate and independent entities. Additionally, the parent/holding compamies in a cartel arrangement cannot capture the benefits that decentralized administrative formats normally offer because they cannot control the distribution of resources annong the subdivisions. Where responsibilities are not divided among parents and subsidiaries, the efficiency justifications that typically accoinpany the use of decentralized structures disappear. Without thein, there is no compelling reason to shield such cnterprises from the application of section 1 . Therefore, they should be held liable under section 1 when their internal agreements result in trade restramts.

\section{B. Applying the Standard}

\section{Businesses Requiring Unified Decisionmaking}

Structural theory holds that when a business produces a single product or engages in a single activity, the necessary decisions will be sufficiently similar and infrequent to commend a central unanagement structure. ${ }^{115}$ Since these businesses do not require the specialization of managemcnt provided by a decentralized structure, a parent will be able to control both the daily operations and the long-term development of the busmess. When manageinent is centralized, any subdivision that the enterprise chooses to create will have virtually no autonomous operating authority. As both a theoretical and practical matter, therefore, the subunits in such a structure are not independent entities. ${ }^{116}$ Accordingly, the test proposed here immunizes thein froin

114. A. Chandler, supra note 16 , at 14 .

115. Id. at 329.

116. Because the standard endorsed here looks only to the patterns of decisionmaking within an enterprise, the fact that the subdivision of a centralized business may be separately incorporated would make no difference. 
antitrust liability under section $1 .^{117}$

\section{Enterprises Employing Decentralized Decisionmaking}

The wide range of business activities of diversified, multiproduct, or multimarket firms generates an enormous quantity of decisions that need to be made. Were such businesses to adopt centralized management structures, their managers would soon be overwhelmed with the sheer volume of decisions to be inade. Moreover, many of the decisions would require a degree of expertise that would be difficult for those with such wide-ranging responsibilities to acquire. Therefore, to preserve the cnterprise's ability to respond effectively to these myriad problems, it is necessary to delegate some decisionmaking authority to the subdivisions. By allowing subdivisions to inake operational, dayto-day decisions, the corporate headquarters is left free to concentrate on longer range business problems and plans. Additionally, by delegating some measure of authority to management at the operations level, a business can ensure that it is equipped to respond quickly and sensitively to production probleins and market fluctuations.

Corporate subunits are not transformed into completely independent entities, however, simply by granting them operational decisionmaking responsibilities. Typically they receive only enough autonomy to enable them to respond to the daily exigencies of their operations. The parents constrain the decisions made by them through a framework of broad policy guidelimes and budgets. It is the parent, therefore, that ultimately determines the present and future allocation of corporate resources and the company's direction. ${ }^{118}$

117. An example of an enterprise to which this centralized decisionmaking exemption would apply is suggested by the facts of Schine Chain Theatres, Inc. v. United States, 334 U.S. 110 (1948). In that case, the three individual defendants were the controlling shareholders and principal officers of the parent company. Additionally, they were the principal officers of each of the wholly owned subsidiaries named as defendants. These individuals not only controlled the parent, but also supervised the operations of the individual subsidiaries. Two of the individual defendants, the Schine brothers, conducted or controlled all of the film-buying negotiations for the entire chain of theaters. The centralization of operating and strategic decisionmaking within the Schine organization would, under the standard proposed here, be sufficient to render the enterprise incapable of conspiracy under $\S 1$.

The student commentator in the Michigan Note, see supra note 4, at 735-36, would also immunize these "sole decisionmaker" enterprises from $\S$ l's proscriptions because they lack the "two separate minds" required by traditional conspiracy law. The Michigan author, however, would expose quasi-autonomous operating divisions to the possibility of conspiracy hability when the parent does not control day-to-day operational decisions. Id. For a discussion of the weaknesses of such an approach, see supra text accompanying notes $35 \& 109-13$.

118. See A. ChANDLER, supra note 16, at 311 . Any inodel of administrative structure is necessarily general. In decentralized operations, there may be some overlap in delegated responsibilities. Strategic decisions- hose concemed with the long-tenn direction of the entire enterprisemay occasionally be made by operational managers. Id. While divisional offices may forinulate some long-term strategic plans, however, they must be carried out within the broad pohicy dictates 
A subsidiary in a decentralized structure, regardless of whether or not it is separately incorporated, slould not be subject to liability for intraenterprise conspiracy if it does not have the authority to make strategic decisions. Where the parent's business plans and marketplace strategy restrict the subdivision's autonomy, it is not an independent center of initiative that Congress designed the anticollusion provisions of section 1 to preserve.

A major advantage of the decisionmaking test is that it allows corporations to exploit the economies associated with delegation of operational authority to subdivisions. A rule that goes beyond discouraging anticompetitive beliavior to penalize a legitinate clioice of business structure imposes a cost that enforcement of section 1 does not require. ${ }^{119}$

\section{Cartel Enterprises}

Reinaining to be considered is the decentralized administrative structure which in practice operates more like a cartel. This "slam" form of decentralization is most likely to be found where an enterprise has grown by acquiring an independent business. ${ }^{120}$ In sucl situations, the possibility that the subunits of the enterprise merely constitute a cartel of former competitors is real. If competitors seeking to avoid antitrust sanctions could group together in a holding company arrangeinent without surrendering any of their authority, it iniglit be mutually advantageous for them to do so. ${ }^{121}$ However, where a corporate parent retaims strategic decisionmaking authority over its affiliated subdivi-

formulated by top management to ensure the efficient and smooth operation of the enterprise. Id.; see also Joseph E. Seagram \& Sons, Inc. v. Hawaiian Oke \& Liquors, Ltd., 416 F.2d 71, 83 (9th Cir. 1969), cert. denied, 396 U.S. 1062 (1970). The Hawailan Oke court acknowledged that whilc the Seagram subdivisions had autonomous sales organizations, "sales and price decisions are not made in a vacuum, but are affected by other corporate activitics . . . " For this reason, the court correctly concluded, autonony in sales decisions alone was insufficient to justify treating the divisions as separate entities from the parent company.

Additionally, the implementation of a subdivision's policies often requires resources-personnel, money, and materials-which only the general office can provide. In short, the subsidiaries remain imescapably subordinated to the overall strategic commands of the parent corporation. As such, they cannot be considered independent entities.

119. A very different conclusion would be reached in cases like General Motors under the proposed nodel. Where, as in the case of General Motors and its sales and financing subdivisions, the parent delegates only operating autonomy to the subdivisions, no plurality of independent actors can be established. The prerequisitc of a $\$ 1$ conbimation or conspiracy, therefore, cannot be met. See supra text accompanying notes 26-29.

120. See, eg., Copperweld, 691 F.2d 310, 320 (7th Cir. 1982) (evidence demonstratcd that the defendant, a newly acquired operating subsidiary enjoyed real autonomy in both day-to-day and policy decisions), cert. granted, 103 S. Ct. 3109 (1983) (No. 82-1260).

121. Participauts in such arrangements could then freely collude in order to reduce outside coinpetition. See supra text accompauying notes 50-53. 
sions, competitors would be unwilling to sacrifice their ability to control their own business strategies in order to jom.

As an example of how a decisionmaking model can detect cartel conduct among loosely affiliated companies, it is useful to look at the facts of Timken ${ }^{122}$ The district court opinion supplies some valuable insights into low the Timken "family" allocated decisions. From the record, it appears that Timken's Britislı and French licensees, while managed and operated together, retained their independence from the American firm. ${ }^{123}$ Altlough Timken acquired substantial interests in both enterprises, it had no control over the "business conduct" of eitlier. ${ }^{124}$ The record therefore strongly suggests that the foreign companies retained their strategic decisionmaking autlority and that the participants sacrificed only the control required to be relinquislied by the anticompetitive agreenients made between them. Under the decisionmaking standard, Timken's decentralization exceeded the scope of a legitimate delegation for a simgle entity. As such, it would be subject to intraenterprise conspiracy liability-regardless of the degree of coinmon ownership shared by the participating coinpanies. ${ }^{125}$

\section{Burdens of Proof}

The standard advocated above requires factfinders to identify the level at which certain kinds of decisions are being made within an enterprise. To prove intraenterprise conspiracy, a plamtiff would be required to prove that the parent corporation delegated to its subdivisions both operational decisionmaking and long-term planning authority. This would be sufficient to establish the subdivision's autonomy and to satisfy the threshold plurality of actors requirement of section 1 .

Traditionally, defendants have invoked the plurality of actors requirement in the form of a "single entity defense" to claims of in-

122. 341 U.S. 593 (1951).

123. See supra note 51.

124. Id. The district court, in fact, considered the two European subsidiaries to be independent and believed that American Timken's stock acquisitions in these two companies were designed to formalize an existing cartel that had divided markets, fixed prices, and otherwise restrained coinpetition both between the Timken companies and by third parties. 83 F. Supp. 284, 306 (N.D. Ohio 1949), aff'd in part and modifted in part, 341 U.S. 593 (1951).

125. Handler \& Sinart's standard that would create a "safe harbor" for wholly owned subsidiaries, see supra note 15 , fails to recognize that even wholly owned subdivisions may be completely independent from the parent. While complete ownership of a subsidiary unay imply greater opportumity for parental control over its activities, this potential nay not necessarily be exploited. See, e.g., Copperweld, 691 F.2d 310, 320 (7th Cir. 1982), cert. granted, 103 S. Ct. 3109 (1983) (No. 82-1260). On the other hand, even a partly owned division may be subject to the control of the parent corporation if the parent holds a controlling percentage of the subdivision's stock and chooses to exercise the control thus acquired. See, e.g., Yellow Cab, 332 U.S. 218, 222 (1947). 
traenterprise conspiracy. ${ }^{126}$ This Comment recommends that the requirement instead be incorporated as an element of the offense, with the plaintiff carrying the burden of proof. Two reasons warrant this shift in burdens. First, as a matter of policy, ${ }^{127}$ an enterprise should be encouraged to adopt the administrative structure that results in the most efficient operation. The possibility of legal sanctions for having chosen a decentralized structure should therefore be minimized. Second, the likelihood that a decentralized corporation is, in reality, a cartel is quite small. To require the defendant to prove this remote possibility in every case would be unduly burdensome. Accordingly, the plaintiff should bear the burden of proving that the defendant's delegation of authority has gone beyond a transfer of operational decisionmaking responsibilities. ${ }^{128}$

\section{The Advantages of the Decisionmaking Model}

The standard proposed liere comports with the ideal criteria outlined earlier. First, the allocation of decisionmaking approach is sensitive to the degree of separation between a parent and subunit. A subsidiary that is granted either no decisionmaking autonomy or only limited operational discretion is not really separate frow the parent enterprise since it is ultimately subject to long-term resource and policy constraints imposed by the corporate parent. On the other hand, when authority for both long- and short-term decisions has been delegated to a subdivision, it becomes an independent source of initiative. As such, it should fall within the scope of section 1 .

Second, the standard encourages inodern, diversified enterprises to employ decentralized structures in order to achieve efficiency. Only when the allocation of authority exceeds the transfer of operational decisionmaking responsibilities would intraenterprise agreements vio-

126. Blecher, supra note 10 , at 218 .

127. Commentators agree that policy considerations offer important guidance in determining to whom the burden of pleading and proving elements should be allocated. See generally C. Clark, Handbook of the Law of Code Pleading 609-10 (2d ed. 1947); F. James \& G. HazARD, Crvil Procedure \$ 2.9, at 82 (1977); Id. \$ 7.8, at 252; Cleary, Presuming and Pleading: An Essay on Juristic Immaturity, 12 STAN. L. REV. 5, 11-12 (1959).

128. See F. JAMES \& G. HAZARD, supra note $127, \S 2.9$, at $81 ; I d . \$ 7.8$, at 252 (the extent to which a party's contention departs from what would normally be expected may work to impose burdens of pleading and proof upon that party); Cleary, supra note 127, at 12-13 (judicial estimates of the probabilities of the situation often affect the allocation of burdens).

The fact that one party has readier access to information about a controverted issue may influence the court to impose the burden of proof on that party. F. JAMES \& G. HAZARD, supra note $127, \S 7.8$, at $251-52$; Cleary, supra note 127 , at 12 . While the defendant in an intraenterprise conspiracy action will have superior access to information concerning the delegation of decisionmaking authority within the enterprise, this single factor does not mandate that the plurahity of actors requirement be retained as a defense. Modern rules of discovery allow the plaintiff ample and early access to the information it will need to inaintain its claim. 
late section 1. In such cases the parent company has sacrificed the benefits derived from maintaining separate spheres of responsibility and has lost control over the subdivision. It therefore should not be able to invoke the efficiency rationales that counsel against the unrestrained exposure of decentralized structures to antitrust conspiracy hability.

The third advantage offered by the decisionmaking test is that it would not be easily inanipulated. Like the functional test, the proposed standard would be applied by looking at both past and present decisionmaking channels and administrative structures. Since decisions will be made at the inost efficient and appropriate level, any effort by a corporation to manipulate its chain of command in order to avoid antitrust hability would be costly to the enterprise and therefore unlikely to occur.

Finally, the decisionmaking approach would limit the number and types of facts considered in assessing the capacity of the actors to conspire. Since the focus of the inquiry will be on the corporate administrative structure, factfinders would only need to consider whether longterm planning and policy decisions are being made by the parent or by subdivision management. Thus, unlike the functional approach, this standard would not require the court to consider myriad unranked factors and to reconcile disparate indicators of autonoiny or integration in order to arrive at a rational outcoine.

\section{ConClusion}

The Supreme Court's doctrine of intraenterprise conspiracy is nonanalytic, overinclusive, and vague. Soine circuit courts, seeking to limit its breadth, have subjected inulticorporate enterprises to a chaotic inultifactored analysis that provides little guidance to either the business community or to other courts considering different enterprises. Under either approach, what is essentially simgle firm conduct is exposed to sanctions intended to be applied only to inultifirm conduct.

This Comment proposes a new standard of intraenterprise conspiracy hability that is consistent with the policies embodied in section 1. ${ }^{129}$ The standard recognizes that the statute was intended to apply only to multiple firm conduct. It therefore rejects those forınulations of the intraenterprise conspiracy doctrine which define separate entities broadly in an attempt to fill the gap between sections 1 and 2 of the Sherman Act. At the same time, the standard remains sensitive to the

129. Any recommendation for reform of $\S 1$ necessarily requires a concomitant reevaluation of $\$ 2$ since the statutes are complementary. Standard Oil v. United States, 221 U.S. 1, 60-61 (1911). Perhaps courts, faced with a mucl narrowed rule of intraenterprise liability under $\S 1$, will reassess $\S 2$ to determine whether to expand its currently limited reach, see supra note 6 , to fill the breach. 
section 1 goal of maintaining multiple centers of independent decisionmaking. Where business subdivisions are empowered to make both strategic and operational decisions, they constitute the independent actors capable of frustrating the policies of section 1. They therefore remain subject to the proscriptions of the statute.

The standard is also inore responsive to modern business realities than are the existing standards. It requires courts to substitute for their nineteenth century stereotype of centrally administered enterprises a more contemporary and realistic appreciation for the spectrum of business structures. Diversified and complex enterprises demand multidivisional administrative structures. Efficiency is promoted by a corporate structure that allows for the delegation of operational decisionmaking to subsidiaries in order to free the parent for entrepreneurial activities. As long as the allocation of decisioninaking authority does not exceed operational discretion, sucl structures are justifiable and should not be discouraged by antitrust liability doctrines.

Ann I. Jones*

* A.B. 1977, Brown University; third-year student, Boalt Hall School of Law, University of California, Berkeley. 